入れるべきであると思われることも少くありませえ。

\section{3. 工場の中の品質管理}

品筫管理について，試驗機のよいものが多くでき て扣りました。あまりきれいでないるらに思机る工 場で日本より良質の糸ができ，織布の持害數も多くな つていることを見て，中はりそのような工場でる品劕 管理がよく行われているのだといらととを感じました。

\section{4. 機械の改善}

紡績機峨は米國でもあまり進んでいない見る人る ありますが，蔚所はやはり進てでいるものと考光られ ます。特に湿打綿とドラコトパートに於て進步が見ら れ，又新しい工場は麾室子鷹突肖なく，自分の機峸加 ら出した應山全部自分の機㳦の中て始末し，清淨機を 通して元に瞦すといらシステムがとられて怙り季す。 文戰争中に機㧴工作が進步して同じ形のるのです新し いすぐれた方㳻で工作しているようですります。

\section{5. 作業の管理}

これ恬グッドハウスキーどングのこと抗といわれま すが，その他に大切なことは作業とのものの管理です

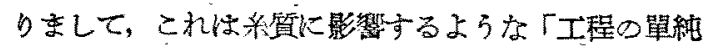
化」をしないといらことに現われて打ります。日本て は精紡機に大きなドラフトをさせる傾向にありますが， 米國で结前䏻で大きなドラフトをし，しかむロービン ダをダブリングしております。アメりカでは日本のス ーパーハイドラフトに興林を持つている人る方ります が探用しようとしているところは全然なく，乙れにつ いては日本人る少し考えるべきですましよう。

\section{6. エアコンデイショニング}

古い工場ではむまりよくできていないところるすり
ましたが，大體炕於て精紡だけでなくすべての工理に 維してェフーコンディショニングが行われて怙りれし た。

\section{7. エ場の清掃}

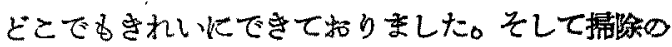

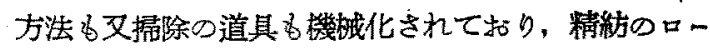
ラーの清担にコンプレストエアーによつてりングスビ ンドルのようなるのを迴して掃除する道具ができて打 りました。これは私も使つてみましたが非常によくで きて扔りました。

\section{8. 部 分 品}

部分品の管理は徹底しております。精紡のトラン゙ 等为一齊に取换えるようにしてい李す。その他各部分 品についる，木管は新しいるのと思われる位きれい， ですり，急所の部品にはよく注意が拂われているした。 以上をまとめてもう一度申しますと，米國では作業

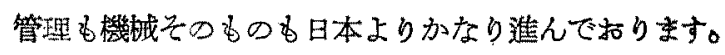
そこでフメリカの機械を少し取入れてみたいのでり

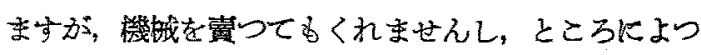
てはあまり見せたがらない位であります。これは日本

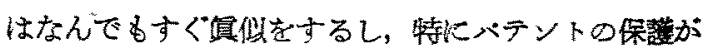
不十分であるとナメッカ人に思われているからですり

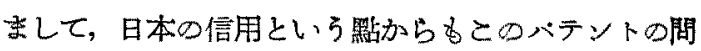
題は氣をつけなければならないるのと思わ㧈ます。

以上ざつな゙くな話で岁りましたが，特間が要りませ んのでこれで私の話を終ることに致します。

（本稿怊昭和26年11月 9 日, 日本交通協會踭堂で行わ

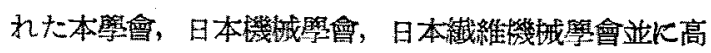

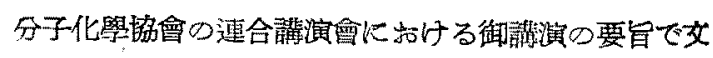
責(編集會蓄に心り)

$$
677: 061.6(43+73)
$$

\title{
米國及び獨逸に於ける研究所の活動狀況（講演要旨）
}

\author{
日東紡綪株式會社富久山工場
}

私性本年 2 月 18 日狗田を出邆致し，米國们約 1 力月 渻在致し，化䊼關保の研究所，工場等を見學致し，後
內藤 萬壽 雄

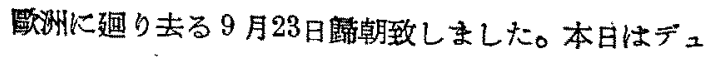
ボン神のデクニカルラボラトリー（以下テタ, ラボと 
略程）大就、て若干招話し，フメリカ各地の研究所見 學の所感の一端を述へ，次いだドイッの二，三の研究 所の樣子を拁話し申上げたいと存します。

\section{1) デュポン社のテクニカルラボラト リイに就いて}

デユボン社はご承知の通り全米に 80 K近い工埸を 持ち，その內の 26 の工場に 36 のラボラトリイがあ り，その他にウィルミルトンに工費 3000 葛ドルをか けて，最近落成したフアンダメンダリサーチラボラ トリイを持つている。

テクニカル，ラボラトyイは，ニュージャーシー州 ウのデニボン最大の工場チャンバーズワークス（Chanbers Works)の中にむつてチャンベースワークスで製 造される各㮔栥料による浸染，捺染の研究，紙及び革 の染色の研究，各種ファインケミカルズの研究，染色 堅牢度の諸試蜸，バッドステイームダイイングに依る 湛徏染色の研究等を行つている。テクラボの人員はダ インタター以下 260 名餘，各研究堂は非常仙篇く設計 され，㝗醶薹はステンレスステー几板で覆われ，どー

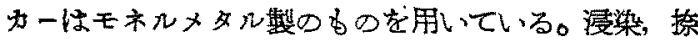
染，樹脂加工，その他フャインケミカルズの筧習に當

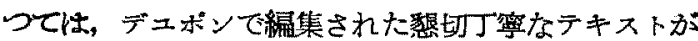
あり，㫮これに基いて宽習している。尚デニポン社の 有機化學藥品の部門㐳入つた青年は全部とのテクラボ 飞於て牛年历至 1 力年の間，會社で出來る染料，䔛料， フォインケミカルズを如何に用いるか， と言う事を充

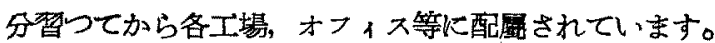

\section{2）テクラボに於ける重要研究に就いて}

テクラボに於ては渭山の重要研究が行われているが, その內の二，三に就いて述へる。

ナイロン，オーロン，デークロン等でデュボンで造 られ西合成繒維の染色。

\section{ナイロンの染色}

ナイロンはつセテートカラー、エィキッドカラー, クロームカラー等で梁色する或を破究して㕲りますが フセテートカラーは應用は简旺ですが，最高の堅安度 を興えず，エィキッドカラーほ堅牢ですが濃色を與え ません，クロームカカラーは染めむらを生し易く色がく すむ，乙れ等の缺呫が出り今佮研究過程にあります。

\section{オーロンの染色}

オーロンはナセテートカラー,パットカラー、ベー
シックカラー，等で染められて括ります。

オーロンは非常に柾水性の繊維ですりますので， オ ーソドックスの染色法でばアヤートカラーで $212^{\circ} \mathrm{F}$ で４時間染めても染料はごく僅かしか人りません。 そこでオーロンの染色法といたしまして

1) Thermosol Process

2) Pad-Pressure-Steam Process

3) Assistant Dyeing 等の方泩が用いられている。

1) "Thermosol" Process

これは石鐱又はシンセテイックデターデェントで分 散させた染浴に "オーロン゙"をバッドして後，高溫で

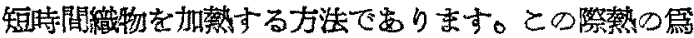
に染料は織物の表面より內部敒行すると考元られて 扣ります。

2) "Pad-Pressure-Steam" Process

高溫の水及はスチームはオーロンを膨潤させる。 パッドブレッシヤステームブロセスはこれを鮰用した るのである。アセテート染料でパッドした後オートク レーブ中で 20 ボンド，250 $\mathrm{F}$ でスチーミングをする。 これとより相當の濃色を得る。

3) Assistant Dyeing

有機のアミノ化合物，フェノール化合物を染浴に混

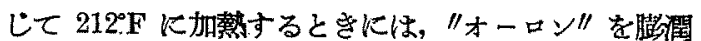
させ，染料をよくキャリイして行くと言われている。 但しこれ等のアシスタントはクレン゙ール，フニリン， フンスラニイル酸等で有震なるのであり, 通風, 防毒 の設俑を要するものと帚われている。

\section{デークロンの染色}

フィラメント，ステープル共に現在瞋劍に研究中で あります。

\section{3）各種ファインケミカルズの應用研究}

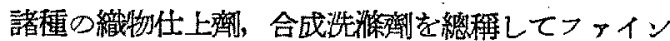
ケミカルズと言つている。スフの樹脂加工臍として Zests が優秀で西ることは既に定棓が告りますがその 他二，三の例を舉げますと，

Duponol-D 染料の撗散を良くするために染浴に加 える。成分性硫酸化オンイルテルコールのナトリゥム

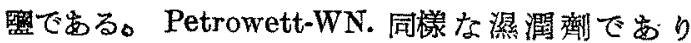

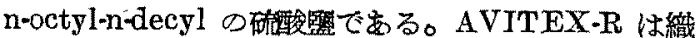

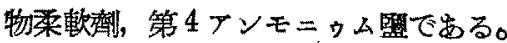

最近人緺，スフの紡浴㕛はヒスコ、スに加えでこ 
“れ等の表面振力を低下せしめ縜を向上せしめる特殊 なファインケミカルズの研究当盛んに行われている。

\section{4）パッドスチームダイインダ の研究}

これは賦に周知のととであるから省略する。以上で デニポン形のテクラポの紹介を終るが，デニポンの研

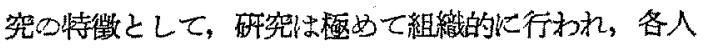

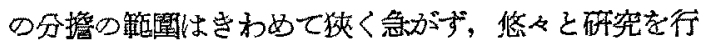
つて特り，デユポン社の融長 Greenwalt (グリーン

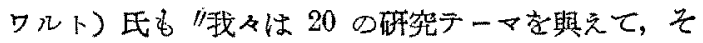
の一つが成功すれば良いとしている゙と演绻していた 位であ。

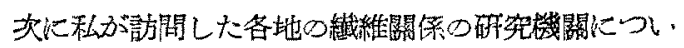
て感じた具柄を二，三迅べたい。

1) Fabric Research Laboratory Boston Mass

2) Haris Research Laboratory Washington, D.C

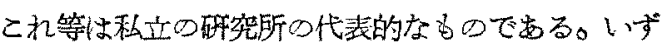
れるが所買は 20 名前後でる。

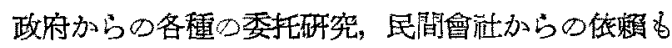
多い。

3) M, I, T, Department of Textile Technologie

Dr，Schwartz が主翌している。非常に基本的な

研究から始めている。光電管を鹳用した測定裝置が 多小。

4) Phladelphia Textile Institute

ダイネル，ピカラ等新しい、合成繊維の紡續，織布の 研究を行つている。

5) North calorina State College Textile Division

新しく今撒張工事をしている。合成瀻維の特性に適

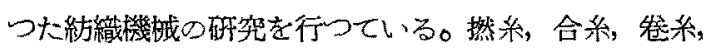
織機，夫及特殊の宣のを研究している。

米國の研究機關声諸間して痛感することの一つは测

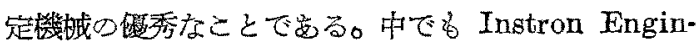
eering Corp $\diamond$ Tensile Strength Tester, 各䄼 Abrasion Tester, 各種 $D$ Air Permeabilty $D$ Tester, 裁面張切測定機等及淡しい限りであつた。

我國て象諸學會，惯業界一體の組織を作りこれ等傮 れた測定機战を極入して，我图のこの種工業の急速の 進步を期待して止み京せん。

\section{5）獨逸に於ける研究所の活動狀況}

私は 8 月下旬より10日要り獨逸炕偝在致し，西下゙ イッの二,三の研究所を見學しました。その印象につ
いて少しく拓話し申上げます。

1) Forschungs institute für makromolekulare chemie in Freiburg

フライブルグのとの研究所は Dr. Staudinger が 主芉して括り，目下 Polyester, Polysaccharid 尿菜 フォルムブルデヒド等の研究，高分子化合物の透埴 の測定等の研究を行つている。この研究所は爆擊の雼

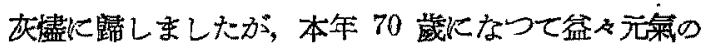
良い, Staudinger 敉授が陣頭に立つて復舊に努めて 扣られる。

2) Textile Forschungs Institnt in Krefeld.

これはドイッの織物の中心地 Krefeld Kすり，Dr。 Weltzien み゙主等している。ここでは各雬の繊維の比 重, 强力, 手の Uniform elongation, 手の Abras-

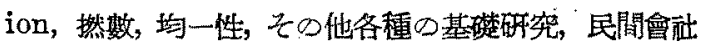
からの委托研究を行つている。

3) Bayer werk in Leverkusen

Bayer werk は現在 Leverkusen, Dormagen, Verdingen, Elberfeld D4 所火工場を持つてい. る。 Leverkusen では 30\% 工業藥品, $25 \%$ 染料, $25 \%$ 醫藥品，20\%アグファフィルム，印畫紙等の生

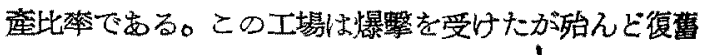

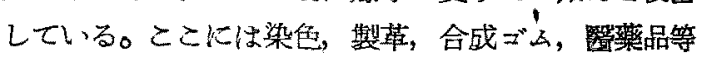
の巨大な研究室がすり，Dr. Bayer が部下の500人と 共化研究に邁進している。最近 Desmodur $\mathbf{R}$ なる新 接着秛，BLANKUPHOR なる新漂白劑，

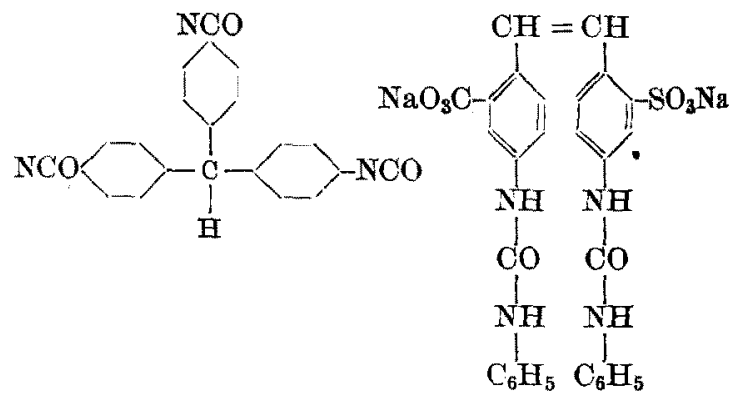

Contebenなる結核の新藥品を造り，又合成ゴムの研 究生笙を再び許可され非常に喜んで、ました。命フタ

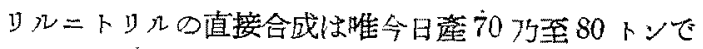
すが，すへて自動調節で工員 2 名で操業している。

原料刀一つ箭酸は

$\mathrm{CO}+\mathrm{NH}_{3} \rightarrow \mathrm{HCONH}_{2} \rightarrow \mathrm{HCN}$

の方法で造つている。 ・

ここで Dr. Bayer が峨ふが多年管心して呼究

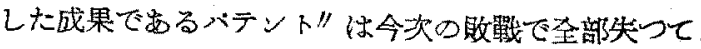


しまつたが，現在次々と新しい製品が出來つつるる。

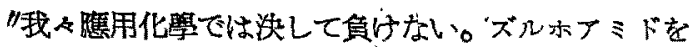
造つてノーー゙ル賞をるらうた Dr. Domagk るバイエ ルの研究所にいたのだ” と自信と满々たる閴志の任ど を示していました。

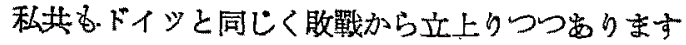
が更に一層の努力と精進を致されねな゙ならぬとつくづく
感じた次第でございます。一向まとまりのない括話を

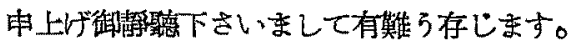

（本稿生炤和26年11月 9 日, 日本交通協會檴堂に特い

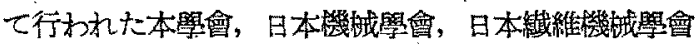

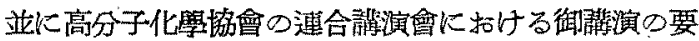
旨で交蛋は編集會議他要り)

\section{? \\ 會告 \\ 春期研究莈表會鿁演者募集}

・昭和27年春期研究發表會を下記の通り開催したしますから下記要項御參照の上舊つ

、て御應募下さん。

（1）を昭和27年5月下旬

(2) こ 万 東京

(3) 犐究發表應募要項

（1）研究發表は 1 件15分以內、質簃應 5 以內

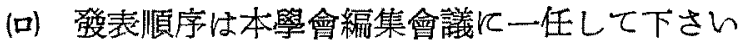

(N) 申込期限任昭和27年3月末日（嚴守）

（4）申込樣式

(1) 講演者の氏名型に勤歌先（連名の場合は講演者に○印）

(口) 護演題目（英文併記）

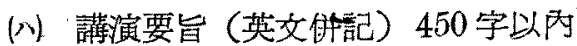

(5) 中 込先

東京都目黑局區內 東京工業大學内 緎維學會宛

（6）日時、場所の詳細は追つて發表いたします 